\title{
PENERAPAN METODE PEMBELAJARAN INKUIRI UNTUK MENINGKATKAN AKTIVITAS DAN HASIL BELAJAR SISWA KELAS IV SD NEGERI 165737 TEBING TINGGI
}

\author{
Ulungen Br Ginting
}

Surel: brgintingulungen@gmail.com

\begin{abstract}
ABSTRAK
Tujuan penelitian ini untuk meningkatkan aktivitas dan hasil belajar siswa pada materi globalisasi dengan menggunakan metode Inkuiri. Subjek penelitian ini adalah siswa kelas IV SD Negeri 165737 Kota Tebing Tinggi Tahun Ajaran 2015/2016, berjumlah 23 orang. Dari hasil test pada siklus I terdapat 7 siswa dari 23 siswa yang sudah mencapai ketuntasan belajar dengan ketuntasan klasikal 30,43\% atau termasuk kategori rendah. Pada siklus II terdapat 13 siswa dari 23 siswa yang sudah mencapai ketuntasan belajar dengan ketuntasan klasikal 56,52\% atau termasuk kategori rendah. Pada siklus III terdapat 19 siswa dari 23 siswa yang sudah mencapai ketuntasan belajar dengan ketuntasan klasikal $82,61 \%$ atau setara dengan kategori tinggi. Hal ini menunjukkan bahwa dengan metode inkuiri dapat meningkatkan hasil belajar siswa pada materi globalisasi di kelas IV SD Negeri 165737 Tahun Ajaran 2015/2016.
\end{abstract}

Kata Kunci : Penerapan Metode Inkuiri, Aktivitas, Hasil Belajar

\section{PENDAHULUAN}

Kemampuan dasar, materi pokok, dan indikator pencapaian hasil belajar yang dicantumkan dalam Standar Nasional merupakan bahan minimal yang harus dikuasai siswa.Oleh karena itu, daerah, sekolah atau guru dapat mengembangkan, menggabungkan, atau menyesuaikan bahan yang disajikan dengan situasi dan kondisi setempat.Realitanya hasil belajar siswa dalam materi Pendidikan Kewarganegaraan belum menunjukkan hasil yang diinginkan.

Kondisi rendahnya hasil belajar siswa dalam materi Globalisasi tercermin juga dalam hasil belajar siswa pada siswa kelas IV SDN 165737.Hal itu dapat diketahui dari rata-rata nilai harian siswa.Pada tiga kali ulangan harian yang diadakan guru dengan kompetensi dasar hakekat negara menunjukkan rata-rata kurang dari nilai 70. Dari ulangan harian yang pernah dilakukan, $+60 \%$ siswa mendapatkan nilai dibawah 70,00. Angka-angka tersebut dapat diartikan, bahwa pemahaman siswa terhadap mata pelajaran Pendidikan Kewarganegaraan tersebut relatif masih rendah. Dengan kata lain, pemahaman siswa SDN 165737 terhadap mata pelajaran Pendidikan Kewarganegaraan yang diajarkan mencapai baru tercapai sekitar 40 persen.

Secara tidak disadari, karena rutinitas tugasnya mengakibatkan guru tidak begitu menghiraukan/peduli apakah siswanya telah atau belum memperoleh pengalaman belajar yang bermakna.Kenyataan hasil belajar siswa dalam materi globalisasi yang rendah tersebut perlu diperbaiki sebab Pendidikan Kewarganegaraan termasuk 
mata pelajaran inti dengan nilai minimum ketuntasan belajar 70 .

Dari uraian di atas muncul kerangka pemikiran bahwa rendahnya nilai mata pelajaran Pendidikan Kewarganegaraan dikarenakan siswa kurang memahami konsep yang selama ini hanya diajarkan guru melalui metode ceramah. Salah satu cara untuk mengatasi hal tersebut adalah pelaksanaan kegiatan tindak lanjut berupa pengajaran dengan menerapkan metode Inkuiri. Hal itu dimaksudkan agar siswa dapat mudah memahami dan menerima materi yang disampaikan guru. Dengan demikian adanya pemahaman konsep tersebut maka akan dapat membantu meningkatkan pemahaman siswa dan akhirnya akan dapat mengatasi rendahnya hasil belajar siswa.

Identifikasi masalah dalam penelitian ini adalah sebagai berikut :

1. Metode yang dipergunakan guru dalam pembelajaran cenderung monoton yakni ceramah dan diskusi.

2. Belum tercapainya hasil belajar siswa sesuai dengan tujuan pengajaran.

3. Proses pembelajaran cenderung bersifat teacher centered atau terpusat pada guru dan guru mendominasi seluruh kegiatan pembelajaran.

Berdasarkan pengamatan dan pengalaman di lapangan terungkap bahwa guru belum memberdayakan seluruh metode pembelajaran yang ada.Hal ini disebabkan karena dalam mengajar mereka yang terpenting adalah materi pelajaran dapat disampaikan secara keseluruhan sesuai dengan alokasi waktunya. Dengan demikian penulis merumuskan masalah sebagai berikut : apakah melalui penerapan metode Inkuiri dapat meningkatkan aktivitas dan hasil belajar siswa dalam materi Globalisasi?

Adapun tujuan dalam penelitian ini ialah:

1.Tujuan Umum

Untuk meningkatkan aktivitas dan hasil belajar siswa dalam materi Globalisasi bagi siswa Sekolah Dasar.

\section{Tujuan Khusus}

Untuk meningkatkan aktivitas dan hasil belajar siswa dalam materi Globalisasi melalui penerapan metode Inkuiri bagi siswa kelas IV semester II SDN 165737 Kota Tebing Tinggi Tahun Ajaran 2015/2016.

\section{METODE PENELITIAN}

Penelitian ini bertempat di SD Negeri 165737 yang terletak di Jl. Baja Kelurahan Tambangan Kecamatan Padang Hilir Kota Tebing Tinggi, dengan alasan peneliti bertugas di sekolah tersebut.

Penelitian ini berlangsung selama \pm 3 (tiga) bulan yang dimulai pada bulan Februari-April 2016 semester II tahun pelajaran 2015/2016 dengan alasan bertepatan dengan materi yang peneliti ajarkan.

Sebagai subyek dalam penelitian ini adalah siswa kelas IV 
SD Negeri 167545 Kota Tebing Tinggi dengan jumlah siswanya adalah 23 Siswa, Laki-laki 11 orang dan perempuan 13 orang. Situasi kelas yang dijadikan subjek penelitian cukup memadai.

Berdasarkan hasil ulangan harian siswa yang sudah diuraikan dalam latar belakang masalah sebelumnya, diperoleh suatu masalah dimana peneliti mendapatkan 26,09\% (6 siswa) yang memenuhi KKM dan 73,91\% (17 siswa) yang di bawah KKM.

Dari soal yang diberikan, diidentifikasi masalah-masalah yang dihadapi siswa secara umum pada materi globalisasi, diantaranya:

1) Siswa kurang mampu memahami konsep globalisasi

2) Siswa kurang mampu memahami unsur-unsur yang terdpat pada globalisasi, Untuk Memberikan contoh sederhana pengaruh globalisasi di lingkungannya

Pada tahap ini peneliti melaksanakan kegiatan belajar mengajar dngan menggunakan metode pembelajaran inkuiri. Adapun hal-hal yang dirancang adalah sebagai berikut :

a. Membuat Rencana Pelaksanaan Pembelajaran (RPP)dengan menggunakan metode pembelajaran inkuiri pada materi globalisasi

b. Mempersiapkan sarana pendukung pembelajaran yang mendukung pelaksanaan tindakan, yaitu : lembar aktivitas siswa (LAS), buku pendidikan kewarganegaraan kelas IV sebagai bahan ajar untuk siswa, spidol, dan lembar observasi.

c. Mempersiapkan instrumen penelitian, yaitu tes hasil belajar I dalam bentuk uraian dengan jumlah soal sebanyak 5 butir dan lembar observasi aktivitas siswa.

Setelah dilakukan rencana tindakan siklus I, maka selanjutnya dilakukan dilakukan pelaksanaan tindakan siklus I sebagai berikut:

a. Melaksanakan pembelajaran sesuai rencana pembelajaran yang telah dibuat sebelumnya.

b. Memberikan beberapa contoh bentuk globalisasi dan menjelaskan mengenai unsurunsur globalisasi

c. Bertanya kepada siswa mengenai unsur-unsur contoh sederhana pengaruh globalisasi di lingkungannya

d. Memberi tes kepada setiap siswa untuk mengetahui hasil belajar siswa

Observasi dilakukan bersamaan dengan tahap pelaksanaan tindakan siklus I, yaitu kegiatan belajar mengajar berlangsung. Observasi dilakukan oleh guru mata pelajaran terhadap hal-hal yang terjadi pada saat pemberian tindakan dengan tujuan agar diketahui apakah kondisi belajar sesuai dengan rencana pelaksanaan pembelajaran.

p-ISSN 2407-4934

e-ISSN 2355-1747 
Pada tahap ini peniliti hasil belajar pendidikan mengumpulkan dan menganalisis kewarganegaraan siswa dalam catatan yang diperoleh selama pembelajaran globalisasi kelas IV observasi dan hasil analisis data SDN 165737. Adapun indikator memperlihatkan keberhasilan dan dalam penelitian ini adalah skor hasil kegagalan dari tindakan yang telah tes dan hasil observasi untuk aktivitas dilaksanakan untuk mengatasi yang diperoleh siswa dalam kesulitan belajar dan tingkat mengikuti pelajaran dengan melalui ketuntasan belajar belum tercapai, maka dilanjutkan pada siklus II.Untuk itu guru merancang suatu perbaikan atau pengembangan dari tindakan kelas.

Apabila siklus 1 belum meningkatkan aktivitas dan hasil belajar pendidikan kewarganegaraan siswa, maka perlu dilaksanakan siklus II. Pada siklus II diadakan kembali permasalahan, perencanaan, pelaksanaan dan pengamatan berdasarkan perbaikan dari siklus I, kemudian refleksi untuk membuat kesimpulan dari hasil yang didapat.

Apabila siklus II belum meningkatkan aktivitas dan hasil belajar pendidikan kewarganegaraan siswa, maka perlu dilaksanakan siklus III. Pada siklus III diadakan kembali permasalahan, perencanaan, pelaksanaan, dan pengamatan berdasarkan perbaikan siklus II, kemudian refleksi untuk membuat kesimpulan dari hasil yang didapat.Bidang studi pendidikan kewarganegaraan membantu untuk mengobservaasi selama kegiatan belajar mengajar berlangsung.

Dalam penelitian ini yang menjadi variabel adalah aktivitas dan

metode pembelajaran inkuiri.

Dalam penelitian ini instrumen yang digunakan berupa tes yang akan dilakukan pada setiap akhir siklus dan lembar Observasi aktivitas (siswa dan guru) yang akan dilakukan pada setiap siklus.

Tes digunakan untuk mengetahui peningkatan hasil belajar siswa meningkat dalam materi globalisasi.Dalam penelitian ini, tes hasil belajar yang digunakan berupa tes tertulis berbentuk essay.Tes diberikan 3 kali, yaitu pada setiap akhir siklus. Tes terdiri dari 5 butir soal untuk siklus I, 5 butir soal untuk siklus II, dan 5 butir soal untuk siklus III.

Lembar observasi digunakan peneliti sebagai pedoman ketika melakukan pengamatan untuk mendapatkan data yang akurat guna mengetahui sejauh mana peningkatan hasil belajar siswa terhadap pelaksanaan

pembelajaran.Pembelajaran dikatakan tuntas jika dari hasil observasi kegiatan pembelajaran termasuk dalam kategori baik.Observasi yang dilakukan bersifat langsung.Untuk melakukan observasi , peneliti 
dibantu oleh observer, yang menjadi observer adalah guru mata pelajaran. Dalam observasi, observer memberi cheklist pada kolom tempat peristiwa muncul.

Aspek yang harus diamati dalam observasi yaitu :

1.Memperhatikan dan mendengarkan penjelasan guru

2.Mengajukan pertanyaan

3.Mengemukakan ide/pendapat

4.Keaktifan dalam kelompok

5.Menjawab pertanyaan guru

6.Menyelesaikan persoalan

7.Mencatat hasil diskusi

8.Menyimpulkan pelajaran

Untuk mendapatkan data penelitian, maka peneliti menggunakan instrumen penelitian yaitu :

1. Observasi dipergunakan merupakan pengamatan langsung terhadap seluruh kegiatan dan perubahan yang terjadi pada saat proses pembelajaran berlangsung. Observasi berguna untuk mengumpulkan data tentang tingkat aktivitas siswa dalam proses belajar melalui metode pembelajaran inkuiri.

2. Tes berguna untuk mengetahui dan mendapat data tentang hasil belajaar siswa. Tes dilakukan pada saat pembelajaran berlangsung.

1. Menghitung tingkat keaktifan siswa
Untuk mengetahui peningkatan aktivitas belajar siswa digunakan rumus :

$$
\mathrm{NR}=\frac{J S}{S M} \mathrm{X} 100 \%
$$

$\mathrm{NR}=$ Persentase rata-rata Aktivitas

JS = Jumlah skor aktivitas yang dilakukan

$\mathrm{SM}=$ Skor maksimal yang dapat dari Aktivitas

Kriteria yang digunakan sebagai dasar untuk mengambil persentase aktivitas belajar siswa yaitu :

$0-4 \%=$ Siswa tidak aktif

$41 \%-60 \%=$ Siswa cukup aktif

$61 \%-79 \%=$ Siswa aktif

$80 \%-100 \%=$ Siswa sangat aktif

2. Menghitung ketuntasan belajar siswa

Untuk mengetahui peningkatan hasil belajar pendidikan kewarganegaraan yang diperoleh dari tes digunakan rumus :

$$
\begin{aligned}
& \text { PHB }=\frac{\text { Skor yang diperoleh siswa }}{\text { Skor maksimal }} \mathbf{x} \\
& 100 \%
\end{aligned}
$$

Keterangan :

PHB : Persentase hasil belajar siswa Dengan kriteria :

Ketuntasan Belajar ditentukan dengan kriteria sebagai berikut :

$<70 \%=$ Kurang

$81-90 \%=$ Baik

$70-80 \%=$ Cukup

$91-100 \%=$ Baik Sekali 
$0 \%-69 \%=$ Siswa belum tuntas belajar

$70 \%-100 \%=$ Siswa telah tuntas belajar

Selanjutnya untuk mengetahui ketuntasan secara klasikal digunakan rumus:

$$
\begin{gathered}
\text { PKK }=\frac{\text { Iumlah siswa yang tuntas belajar }}{\text { Jumlah seluruh siswa }} \mathbf{x} \\
100 \%
\end{gathered}
$$

Keterangan :

PKK : Persentase ketuntasan klasikal Kiteria ketuntasan :

$\%-69 \%=$ Siswa belum tuntas belajar

$70 \%-100 \%=$ Siswa telah tuntas belajar

Jika siswa sudah mencapai hasil $\geq 70 \%$ maka siswa dapat dikatakan berhasil. Secara keseluruhan jika terdapat $80 \%$ siswa yang berhasil mencapai nilai $\geq 70 \%$ maka pembelajaran pendidikan kewarganegaraan siswa dikatakan baik/tuntas.

Apabila terdapat $80 \%$ siswa yang telah mencapai hasil belajar $\geq$ 70, maka dengan demikian ada peningkatan hasil belajar matematika yang diajar dengan metode pembelajaran Inkuiri pada materi kubus dan balok di kelas IV SDN 165737 Kota Tebing Tinggi Tahun Ajaran 2015/2016, dengan kata lain hipotesis yang diajukan diterima kebenarannya.

\section{HASIL DAN PEMBAHASAN}

Pada bagian ini peneliti akan membahas tentang hasil penelitian yang telah dilakukan di kelas IV SDN 165737 Kota Tebing Tinggi. Hasil penelitian ini akan diuraikan berdasarkan hasil yang telah dilakukan dalam 3 tahapan yang berlangsung dalam 3 siklus. Di bawah ini akan diuraikan hasil penelitian yang telah berlangsung berdasarkan siklus dan tahapan yang dilakukan.

Siklus 1 dilaksanakan dalam dua pertemuan, pertemuan pertama pada hari senin tanggal 15 februari 2016 dan pertemuan kedua pada hari kamis tanggal 18 februari 2016, pembahasan materi yaitu Memberikan contoh sederhana pengaruh globalisasi di lingkungannya. Tahapan-tahapan yang dilakukan oleh peneliti selama proses pembelajaran siklus I adalah sebagai berikut :

Berdasarkan hasil observasi terdahulu yang dilakukan peneliti di sekolah Dasar kelas IV SDN 165737 kota Tebing Tinggi diperoleh aktivitas siswa selama proses belajar mengajar berlangsung masih rendah. Ini dapat dilihat dari siswa cenderung pasif dan kurang bersungguh-sungguh dalam belajar,ada yang sedang bercerita dengan teman sebangkunya, dan ada juga siswa yang matanya seolah-olah memperhatikan pelajaran padahal pikirannya tidak terpusat 
kepelajaran, ini terbukti ketika guru bertanya, dia hanya diam tidak merespon.peran guru yang lebih dominan, siswa hanya menerima pelajaran yang diberikan guru.

Dan berdasarkan hasil ulangan harian siswa yang sudah diuraikan di latar belakang dan dapat dilihat pada lampiran, diperoleh suatu masalah dimana peneliti mendapatkan 26,07\% (6 siswa) yang memenuhi KKM dan $73,91 \%$

(17 siswa) yang di bawah KKM.

Pada tahap ini peneliti melaksanakan kegiatan belajar mengajar dengan menggunakan metode Inkuiri. Adapun hal-hal yang dirancang adalah sebagai berikut :

a. Membuat Rencana Pelaksanaan Pembelajaran (RPP) dengan menggunakan metode pembelajaran Inkuiri pada materi globalisasi

b. Mempersiapkan sarana pendukung pembelajaran yang mendukung pelaksanaan tindakan, yaitu : Lembar Aktivitas Siswa (LAS), buku Pendidikan Kewarganegaraan kelas IV sebagai bahan ajar untuk siswa, spidol, dan lembar observasi.

c. Mempersiapkan instrumen penelitian, yaitu tes hasil belajar I dalam bentuk uraian dengan jumlah soal sebanyak 5 butir dan lembar observasi aktivitas siswa.

Setelah dilakukan perencanaan, maka selanjutnya dilakukan pelaksanaan siklus 1 . Adapun kegiatan yang dilakukan adalah :

a. Kegiatan awal

Guru mengawali pembelajaran dengan mengucapkan salam, guru mengkondusifkan keadaan kelas. Guru menginformasikan kepada siswa tentang materi yang akan dipelajari pada pertemuan hari ini, yaitu Memberikan contoh sederhana pengaruh globalisasi di lingkungannya, siswa dimotivasi apabila materi ini dikuasai dengan baik oleh siswa, maka akan bermanfaat dalam menyelesaikan soal-soal dalam kehidupan seharihari.

Guru menginformasikan bahwa pembelajaran akan dilaksanakan secara kooperatif dengan metode Inkuiri. Guru menjelaskan langkah-langkah pembelajaran metode inkuiri kepada siswa, yaitu siswa akan dibagi dalamkelompok untuk mendiskusikan masalah yang disajikan dalam LAS, siswa berdiskusi untuk merumuskan jawaban sementara ( hipotesis ), mengumpulkan data, menguji hipotesis dengan presentasi, dan menarik kesimpulan dari hasil diskusi.

\section{b. Kegiatan Inti}

Kegiatan inti meliputi :

1. Memberikan pertanyaanpertanyaan yang berkaitan dengan globalisasi yang ada di sekitar lingkungan, 
2. Memberikan masalah kepada siswa berupa pertanyaanpertanyaan yang harus dijawab siswa,

3. Memberikan kesempatan kepada siswa untuk mengemukakan pendapatnya mengenai permasalahan yang diajukan guru,

4. Untuk menguji kebenaran dari siswa, guru membimbing siswa untuk mengumpulkan data dan menganalisis data,

5. Memberikan kesempatan kepada siswa bertaya apabila ada yang kurang dimengerti,

6. Guru memberikan LAS kepada siswa dan meminta siswa membentuk kelompok yang beranggotakan 2 orang atau hanya dengan teman sebangku untuk mengerjakan soal-soal pada Lembar Aktivitas Siswa yang telah dibagikan sebelumnya.

c. Penutup

Diakhir pembelajaran, guru dan siswa membuat kesimpulan tentang materi yang telah dipelajari. Kemudian guru memberitahukan bahwa pertemuan berikutnya tepatnya tanggal 19 februari 2016 akan diadakan siklus 1 .

Pengamatan dilakukan bersama dengan pelaksanaan tindakan I, yaitu ketika kegiatan belajar mengajar berlangsung. Observasi ini dilakukan oleh guru Pendidikan Kewarganegaraan. Observasi ini bertujuan untuk mengetahui sejauh mana peningkatan hasil belajar siswa terhadap pelaksananaan pembelajaran. Hasil observasi aktivitas siswa pada siklus I dapat dilihat pada tabel di bawah ini :

Tabel I

Hasil Observasi Pada Siklus I

\begin{tabular}{|c|c|c|c|c|c|c|}
\hline $\mathrm{Nc}$ & Aspek yang diamati & Jumlah & Persentase & Baik & Cukup & Kurang \\
\hline$T$ & $\begin{array}{l}\text { Memperhatikan dan } \\
\text { Mendengarkan } \\
\text { Penjelasan guru }\end{array}$ & 16 & $69,57 \%$ & & $\sqrt{ }$ & \\
\hline 2 & $\begin{array}{l}\text { Mengajukan } \\
\text { Pertanyaan }\end{array}$ & 12 & $52,17 \%$ & & $\sqrt{ }$ & \\
\hline 3 & $\begin{array}{l}\text { Mengemukakan } \\
\text { Ide/pendapat }\end{array}$ & 5 & $21,73 \%$ & & & $\sqrt{ }$ \\
\hline 4 & $\begin{array}{l}\text { Keaktifan dalam } \\
\text { Kelompok }\end{array}$ & 9 & $39,13 \%$ & & & $\sqrt{ }$ \\
\hline 5 & $\begin{array}{l}\text { Menjawab pertanyaan } \\
\text { Guru }\end{array}$ & 6 & $26,07 \%$ & & & $\sqrt{ }$ \\
\hline
\end{tabular}

p-ISSN 2407-4934

e-ISSN 2355-1747 
6 Menyelesaikan 3

Persoalan

7 Mencatat hasil diskusi

11

8 Menyimpulkan

pelajaran

Dari tabel di atas bahwa pada pengamatan kedua pada aktivitas siswa memperoleh persentase sebesar $37,5 \%$. Setelah pemberian tindakan dilaksanakan maka diberikan evaluasi akhir pembelajaran yaitu tes yang terdiri dari 5 soal uraian tes kepada siswa.Hal ini bertujuan untuk mengetahui keberhasilan tindakan yang diberikan.

a. Refleksi

1. Kelemahan guru pada siklus I

1. Guru masih kurang mampu menyampaikan materi pelajaran agar dapat dipahami dan dimengerti siswa

2. Pengertian yang kurang tegas dalam mendefinisikan pengaruh globalisasi di lingkungan

3. Strategi dalam menjawab soal yang digunakan tidak tepat

4. Guru masih belim bisamenguasai kelas

2. Penyebab kelemahan guru pada siklus I

a. Kurangnya perhatian guru dalam proses penyelesaian ssuatu masalah

b. Guru masih beriorentasi pada jawaban akhir

c. Interaksi antara guru dan siswa masih kurang
$13,04 \%$

$47,83 \%$

$30,43 \%$

d. Penerapan yang diterapkan dalam pembelajaran belum dikuasai dengan baik

e. Dalam menertibkan siswa ketika pembagian kelompok belum maksimal

3. Kelebihan guru pada siklus I

a. Pelaksanaan tindakan pada siklus I guru bisa mulai memguasai kelas dan menertibkan siswa pada saat membagi kelompok

b. Guru mulai bisa menyampaikan materi pelajaran khususnya dalam mendefinisikan sifat-sifat globalisasi, sehingga strategi menjawab soal yang digunakan hampir tepat

4. Penyebab kelebihan guru pada siklus I

a. Guru memotivasi siswa sehingga merangsang terjadinya interaksi antar siswa dan melakukan kegiatan terbimbing

b. Guru sudah bisa menciptakan suasan kondusif

b. Evaluasi.

Berdasarkan hasil evaluasi yang diberikan kepada siswa, maka didapat hasilnya sebagai berikut : 
Tabel II

Tingkat Penguasaan Dan Ketuntasan Hasil Belajar Individual Siklus I

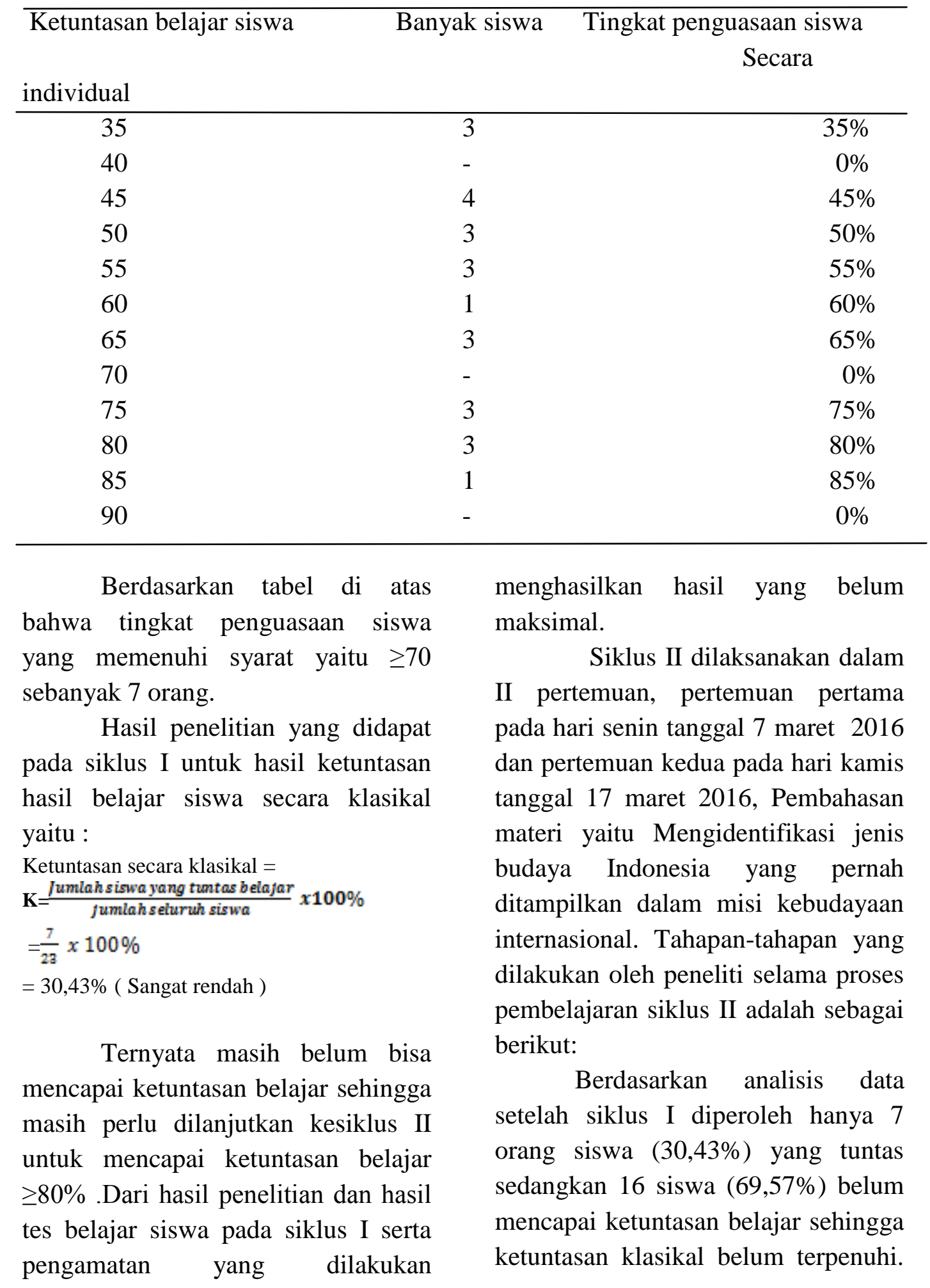


Selain itu hasil observasi pada aktivitas siswa selama pembelajaran berlangsung diperoleh jumlah siswa yang memiliki persentase aktivitas $37,5 \%$.

Maka dalam pelaksanaan siklus II ini masalah yang akan diatasi adalah:

a. Siswa masih kurang aktif selama proses belajar mengajar berlangsung,

b. Siswa masih takut bertanya kepada guru,

c. Siswa masih takut mengemukakan pendapatnya,

d. Kemampuan siswa dalam mengerjakan soal masih rendah, hal ini dapat dilihat dari banyaknya kesalahan yang dilakukan oleh siswa dalam mengerjakan tes,

e. Hasil belajar Pendidikan Kewarganegaraan siswa masih rendah, karena masih 30,43\% siswa yang tuntas.

Pada tahap ini peneliti melaksanakan kegiatan belajar mengajar dengan menggunakan metode pembelajaran Inkuiri. Adapun hal-hal yang dirancang adalah :

a. Guru memperbaiki dan mengembangkan rencana pelaksanaan dan pembelajaran berdasarkan permasalahan yang ditemukan pada siklus I,

b. Guru lebih aktif membimbing dan mengarahkan siswa untuk lebih aktif dalam materi globalisasi,

c. Guru lebih mendekatkan diri agar siswa tidak malu bertanya dan mengemukakan pendapatnya, serta guru lebih mengenalkan metode inkuiri,

d. Menyusun RPP dengan metode inkuiri tentang materi yang akan diajarkan,

e. Mempersiapkan lembar aktivitas siswa sesuai dengan materi yang diajarkan,

f. Menyusun lembar observasi pembelajaran,

g. Menyusun tes hasil belajar siswa yang berbentuk uraian

Setelah melakukan tahap perencanaan, maka akan dilakukan tahap pelaksanaan. Adapun kegiatan yang dilakukan, yaitu :

a. Kegiatan Awal

Guru mengawali pembelajaran dengan mengucapkan salam. Guru mengkondusifkan keadaan kelas. Guru menginformasikan kepada siswa tentang materi yang aakan dipelajari. Dengan tanya jawab, guru mengingatkan tentang pelajaran globalisasi sebelumnya. Guru menginformasikan bahwa pembelajaran akan dilaksanakan secara kooperatif dengan metode inkuiri. Sama seperti pertemuan sebelumnya.

b. Kegiatan Inti Kegiatan inti meliputi :

1. Memberikan pertanyaanpertanyaan yang berkaitan dengan globalisasi,

2. Memberikan masalah kepada siswa berupa pertanyaan- 
pertanyaan yang harus dijawab siswa,

3. Memberikan contoh-contoh yang akan dipelajari,

4. Memberikan kesempatan siswa untuk mengemukakan pendapatnya mengenai permasalahan yang diajukan guru,

5. Untuk menguji kebenaran dari siswa, guru membimbing siswa untuk mengumpulkan data dan menganalisis data,

6. Memberikan kesempatan kepada siswa bertanya apabila ada yang kurang dimengerti,

7. Guru meminta siswa mengerjakan soal-soal pada Lembar Aktivitas Siswa yang telah dibagikan,

8. Guru mengawasi dan membantu siswa apabila ada siswa yang kesulitan dalam pengerjaan Lembar Aktivitas. c. Penutup

Diakhir pembelajaran guru dan siswa membuat kesimpulan tentang materi yang telah dipelajari. Kemudian guru memberitahukan bahwa pertemuan berikutnya tepatnya tanggal 17 Maret 2016akan diadakan tes siklus II.

Pengamatan dilakukan bersama dengan pelaksanaan tindakan II, yaitu ketika kegiatan belajar mengajar berlangsung. Observasi ini dilakukan oleh guru Pendidikan Kewarganegaraan . Observasi ini bertujuan untuk mengetahui sejauh mana peningkatan hasil belajar siswa terhadap pelaksananaan pembelajaran.

Hasil observasi aktivitas siswa pada siklus II dapat dilihat pada tabel III di bawah ini :

Tabel III

Hasil Observasi Pada Siklus Ii

\begin{tabular}{|c|c|c|c|c|c|c|}
\hline No & Aspek yang diamati & Jumlah & Persentase & Baik & Cukup & Kurang \\
\hline 1 & $\begin{array}{l}\text { Memperhatikan dan } \\
\text { Mendengarkan } \\
\text { Penjelasan guru }\end{array}$ & 18 & $78,26 \%$ & $\checkmark$ & & \\
\hline 2 & $\begin{array}{l}\text { Mengajukan } \\
\text { Pertanyaan }\end{array}$ & 16 & $69,57 \%$ & & $\sqrt{ }$ & \\
\hline 3 & $\begin{array}{l}\text { Mengemukakan } \\
\text { Ide/pendapat }\end{array}$ & 13 & $56,52 \%$ & & & $\sqrt{ }$ \\
\hline 4 & $\begin{array}{l}\text { Keaktifan dalam } \\
\text { Kelompok }\end{array}$ & 11 & $47,83 \%$ & & & $\sqrt{ }$ \\
\hline
\end{tabular}


5 Menjawab pertanyaan

Guru

6 Menyelesaikan

Persoalan

7 Mencatat hasil diskusi

8 Menyimpulkan

pelajaran
13

$56,52 \%$

$34,78 \%$

$65,22 \%$

$43,49 \%$
Dari tabel di atas bahwa pada pengamatan kedua pada aktivitas siswa memperoleh persentase sebesar $56,52 \%$. Setelah pemberian tindakan dilaksanakan maka diberikan evaluasi akhir pembelajaran yaitu tes yang terdiri dari 5 soal uraian tes kepada siswa.Hal ini bertujuan untuk mengetahui keberhasilan tindakan yang diberikan.

a. Refleksi

1. Kelemahan guru pada siklus II

a. Hasil observasi dan evaluasi pelaksanaan tindakan siklus II belum mencapai indikator kinerja yang telah ditetapkan

b. Pelaksanaan pembelajaran pada siklus II belum maksimal, yaitu hanya sekitar $70 \%$ kegiatan pembelajaran yang terlaksana.

2. Penyebab kelemahan guru pada siklus II

a. Pada siklus II siswa masih ada yang bertanya ketika menyelesaikan tes yang guru berikan

b. Siswa yang belum sepenuhnya memperhatikan apa yang telah dijelaskan oleh guru

c. Materi yang diajarkan tidak sepenuhnya dipahami oleh siswa d. Siswa belum sepenuhnya menjawab soal-soal yang diajukan oleh guru dan siswa belum berani menanggapi jawaban yang diajukan oleh temannya.

3. Kelebihan guru pada siklus II

a. Dapat meratakan peningkatan aktivitas siswa dan keterlibatan siswa, diawal pertemuan, guru atau peneliti lebih mengarahkan siswa untuk berperan aktif dalam proses pembelajaran

b. Dapat meningkatkan hasil belajar perlu memperhatikan tugas-tugas siswa seperti mengoreksi PR dan mengembalikan kepada mereka

4. Penyebab kelebihan guru pada siklus II

a. Waktu berjalannya kegiatan belajar mengajar siswa lebih aktif bertanya, dimana siswa sebagai model bukan hanya siswa yang paling cepat menangkap materi pelajaran, tetapi memacu prestasi atau 
memotivasi siswa yang lama menangkap juga

b. Siswa aktif dalam mengerjakan tugas PR yang diberikan
Berdasarkan hasil evaluasi yang diberikan kepada siswa, maka didapat hasilnya sebagai berikut :

Tabel IV

Tingkat Penguasaan Dan Ketuntasan Hasil Belajar Individual Siklus II

\begin{tabular}{ccc}
\hline $\begin{array}{l}\text { Ketuntasan belajar siswa } \\
\text { siswa } \\
\text { individual }\end{array}$ & Banyak siswa & $\begin{array}{r}\text { Tingkat penguasaan } \\
\text { Secara }\end{array}$ \\
\hline 35 & & $35 \%$ \\
40 & 2 & $0 \%$ \\
45 & - & $45 \%$ \\
50 & 3 & $50 \%$ \\
55 & 3 & $55 \%$ \\
60 & 2 & $60 \%$ \\
65 & 1 & $65 \%$ \\
70 & 3 & $70 \%$ \\
75 & 4 & $75 \%$ \\
80 & 5 & $80 \%$ \\
85 & 3 & $85 \%$ \\
90 & 1 & $0 \%$
\end{tabular}

Berdasarkan tabel di atas bahwa tingkat penguasaan siswa yang memenuhi syarat yaitu $\geq 70$ sebanyak13 orang.

Hasil penelitian yang didapat pada siklus I untuk hasil ketuntasan hasil belajar siswa secara klasikal yaitu :

Ketuntasan secara klasikal $=$ $\mathrm{K}=\frac{\text { Jumlah siswa yang tuntas belajar }}{\text { jumlah seluruh siswa }} \times 100 \%$ $=\frac{13}{23} \times 100 \%$ $=56,52 \%($ Rendah $)$
Ternyata masih belum bisa mencapai ketuntasan belajar sehingga masih perlu dilanjutkan kesiklus III untuk mencapai ketuntasan belajar $\geq 80 \%$.Dari hasil penelitian dan hasil tes belajar siswa pada siklus II serta pengamatan yang dilakukan menghasilkan hasil yang belum maksimal.

Siklus II dilaksanakan dalam II pertemuan, pertemuan pertama pada hari senin tanggal 28 maret 2016 dan pertemuan kedua pada hari kamis tanggal 7 april 2016, Pembahasan materi yaitu Mengidentifikasi jenis 
budaya Indonesia yang pernah ditampilkan dalam misi kebudayaan internasional. Tahapan-tahapan yang dilakukan oleh peneliti selama proses pembelajaran siklus II adalah sebagai berikut :

Berdasarkan analisis data setelah siklus II diperoleh hanya 13 orang siswa $(56,52 \%)$ yang tuntas sedangkan 10 siswa $(69,57 \%)$ belum mencapai ketuntasan belajar sehingga ketuntasan klasikal belum terpenuhi. Selain itu hasil observasi pada aktivitas siswa selama pembelajaran berlangsung diperoleh jumlah siswa yang memiliki persentase aktivitas $56,52 \%$

Maka dalam pelaksanaan siklus II ini masalah yang akan diatasi adalah:

a. Siswa masih kurang aktif selama proses belajar mengajar berlangsung, b.Siswa masih takut bertanya kepada guru,

c. Siswa masih takut mengemukakan pendapatnya,

d. Hasil belajar Pendidikan Kewarganegaraan siswa masih rendah, karena masih 30,43\% siswa yang tuntas.

Pada tahap ini peneliti melaksanakan kegiatan belajar mengajar dengan menggunakan metode pembelajaran Inkuiri. Adapun hal-hal yang dirancang adalah :

a. Guru memperbaiki dan mengembangkan rencana pelaksanaan dan pembelajaran berdasarkan permasalahan yang ditemukan pada siklus I, b. Guru lebih aktif membimbing dan mengarahkan siswa untuk lebih aktif dalam materi globalisasi,

c. Guru lebih mendekatkan diri agar siswa tidak malu bertanya dan mengemukakan pendapatnya, serta guru lebih mengenalkan metode inkuiri,

d. Menyusun RPP dengan metode inkuiri tentang materi yang akan diajarkan,

e. Mempersiapkan lembar aktivitas siswa sesuai dengan materi yang diajarkan,

f. Menyusun lembar observasi pembelajaran,

g. Menyusun tes hasil belajar siswa yang berbentuk uraian

Setelah melakukan tahap perencanaan, maka akan dilakukan tahap pelaksanaan. Adapun kegiatan yang dilakukan, yaitu :

a. Kegiatan Awal

Guru mengawali pembelajaran dengan mengucapkan salam. Guru mengkondusifkan keadaan kelas. Guru menginformasikan kepada siswa tentang materi yang aakan dipelajari. Dengan tanya jawab, guru mengingatkan tentang pelajaran globalisasi sebelumnya. Guru menginformasikan bahwa pembelajaran akan dilaksanakan secara kooperatif dengan metode inkuiri. Sama seperti pertemuan sebelumnya.

b. Kegiatan Inti

Kegiatan inti meliputi: 
1. Memberikan pertanyaanpertanyaan yang berkaitan dengan globalisasi,

2. Memberikan masalah kepada siswa berupa pertanyaanpertanyaan yang harus dijawab siswa,

3. Memberikan contoh-contoh yang akan dipelajari,

4. Memberikan kesempatan siswa untuk mengemukakan pendapatnya mengenai permasalahan yang diajukan guru,

5. Untuk menguji kebenaran dari siswa, guru membimbing siswa untuk mengumpulkan data dan menganalisis data,

6. Memberikan kesempatan kepada siswa bertanya apabila ada yang kurang dimengerti,

7. Guru meminta siswa mengerjakan soal-soal pada Lembar Aktivitas Siswa yang telah dibagikan,
8. Guru mengawasi dan membantu siswa apabila ada siswa yang kesulitan dalam pengerjaan Lembar Aktivitas.

c. Penutup

Diakhir pembelajaran guru dan siswa membuat kesimpulan tentang materi yang telah dipelajari. Kemudian guru memberitahukan bahwa pertemuan berikutnya tepatnya tanggal 7 april 2016 akan diadakan tes siklus III.

Pengamatan dilakukan bersama dengan pelaksanaan tindakan II, yaitu ketika kegiatan belajar mengajar berlangsung. Observasi ini dilakukan oleh guru Pendidikan Kewarganegaraan. Observasi ini bertujuan untuk mengetahui sejauh mana peningkatan hasil belajar siswa terhadap pelaksananaan pembelajaran. Hasil observasi aktivitas siswa pada siklus II dapat dilihat pada tabel di bawah ini :

Tabel V

Hasil Observasi Pada Siklus III

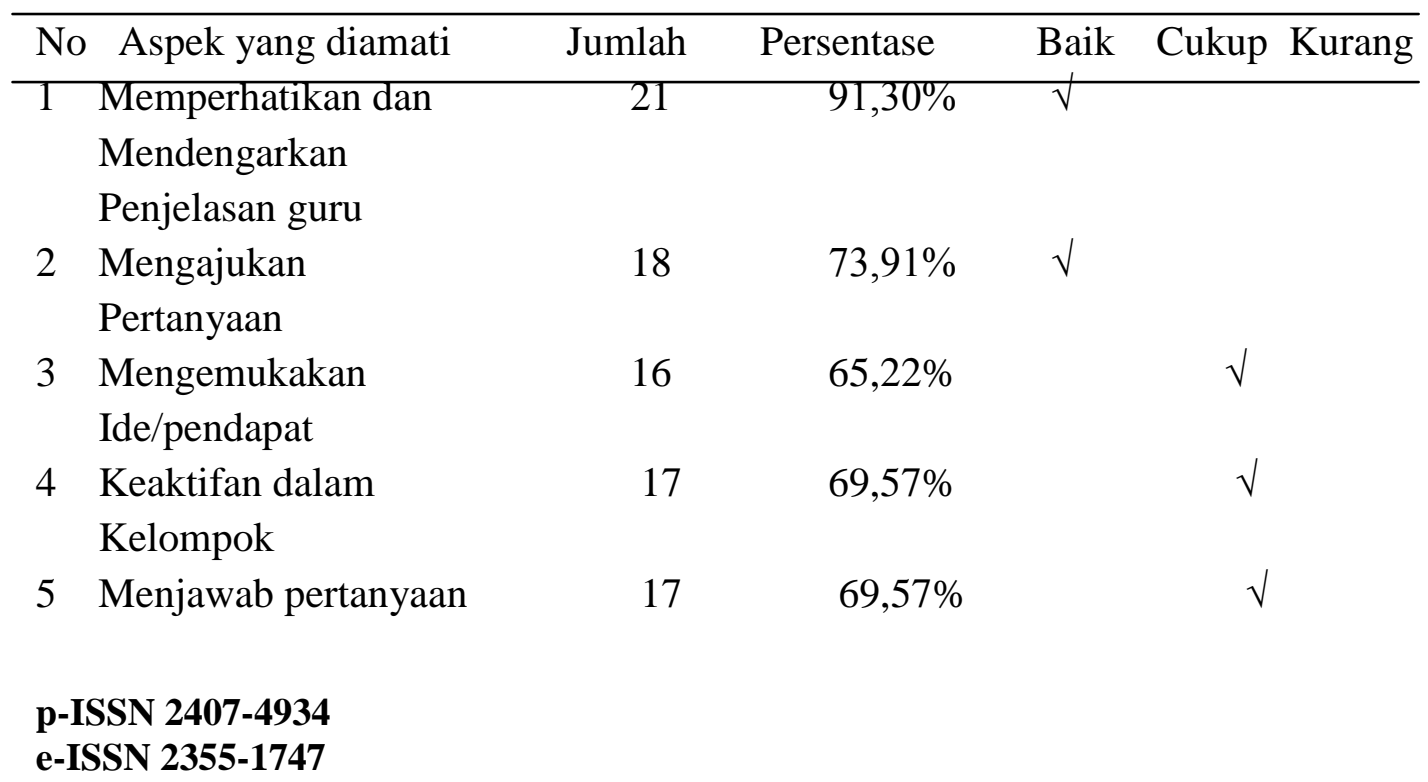


Guru

6 Menyelesaikan 22

Persoalan

7 Mencatat hasil diskusi

$18 \quad 78,26 \%$

8 Menyimpulkan

10 $86,96 \% \quad \sqrt{ }$ pelajaran

Dari tabel di atas bahwa pada pengamatan ketiga pada aktivitas siswa memperoleh persentase sebesar $80,9 \%$. Setelah pemberian tindakan dilaksanakan maka diberikan evaluasi akhir pembelajaran yaitu tes yang terdiri dari 5 soal uraian tes kepada siswa.Hal ini bertujuan untuk mengetahui keberhasilan tindakan yang diberikan.

\section{a. Refleksi}

1. Kelemahan siswa pada siklus III

a) Siswa masih belum bisa sepenuhnya memahami konsep pembelajaran secara inkuiri

b) Siswa masih mengalami kesulitan dalam menyelesaikan soal latihan

c) Siswa masih belum terbiasa bertanya dan mengemukakan pendapatnya

2. Penyebab kelemahan guru pada siklus III

a) Belum terbiasa dengan metode pembelajaran inkuiri.Metode inkuiri belum pernah dilaksanakan siswa sebelumnya oleh guru setempat

b) Sebagian besar siswa tidak memperhatikan penjelasan guru saat menyampaikan materi

c) Siswa tidak mengerti hal apa yang ingin ditanyakan

3. Kelebihan siswa pada siklus III

a) Aktivitas siswa dalam proses belajar mengajar sudah mengarah kepada penerapan metode pembelajaran inkuiri

b) Terjadi peningkatan hasil belajar belajar siswa dari $56,52 \%$ pada siklus II, menjadi $82,61 \%$ pada sikus III

c) Terjadi peningkatan observasi aktivitas siswa dari $56,52 \%$ pada siklus II, menjadi $80,9 \%$ pada siklus III

4. Penyebab kelebihan siswa pada siklus III

a) Siswa sudah mampu membangun kerja sama dalam kelompok untuk memahami tugas yang diberikan kepada masing-masing kelompok

b) Siswa sudah mampu mengerjakan tugas dengan baik.

Berdasarkan hasil evaluasi yang diberikan kepada siswa, maka didapat hasilnya sebagai berikut : 
Tabel VI

Tingkat Penguasaan Dan Ketuntasan Hasil Belajar Individual Siklus Iii

\begin{tabular}{rcc}
\hline $\begin{array}{l}\text { Ketuntasan belajar siswa } \\
\text { siswa }\end{array}$ & Banyak siswa & Tingkat penguasaan \\
individual & & Secara \\
\hline 35 & & $0 \%$ \\
40 & - & $0 \%$ \\
45 & - & $0 \%$ \\
50 & - & $50 \%$ \\
55 & 2 & $55 \%$ \\
60 & 1 & $0 \%$ \\
65 & - & $65 \%$ \\
70 & 1 & $0 \%$ \\
75 & - & $75 \%$ \\
80 & 10 & $80 \%$ \\
85 & 5 & $85 \%$ \\
90 & 2 & $90 \%$ \\
\hline
\end{tabular}

Berdasarkan tabel di atas bahwa tingkat penguasaan siswa yang memenuhi syarat yaitu $\geq 70$ sebanyak19 orang.

Hasil penelitian yang didapat pada siklus I untuk hasil ketuntasan hasil belajar siswa secara klasikal yaitu :

Ketuntasan secara klasikal = $\mathrm{K}=\frac{\text { jumlah siswa yang tuntas belajar }}{\text { jumlah seluruh siswa }} \times 100 \%$ $=\frac{19}{23} \times 100 \%$ $=82,61 \%$ ( Tinggi )

Berdasarkan tabel di atas dapat dilihat bahwa hasil tes III di siklus III diperoleh nilai $\geq 70$ sebanyak 19 orang siswa $(82,61 \%)$, ini berarti bahwa pada siklus III sudah mengalami peningkatan secara klasikal dan telah mencapai kategori ketuntasa secara klasikal. Maka peniliti memutuskan untuk tidak melanjutkan tindakan ke siklus selanjutnya dann penelitian berakhir di siklus III saja, karena hasil yang diperoleh telah mencapai $\geq 80 \%$.

Pembahasan dalam penelitian tindakan kelas didasarkan atas hasil penelitian dan catatan peneliti selama melakukan penelitian.Baik hasil penelitian berupa tes maupun hasil observasi yang dilakukan terhadap siswa. Berdasarkan hasil penelitian yang telah diberikan tindakan , diperoleh aktivitas dan hasil belajar siswa yang meningkat dari siklus I,II,dan sampai ke siklus III setelah 
diadakan pembelajaran dengan metode inkuiri pada materi kubus daan balok.kData-data yanng diperoleh dari siklus I, II, III adalah sebagai berikut:

Pada siklus I didapat jumlah siswa yang telah tuntas belajar adalah 7 orang dengan jumlah siswa adalah 23 orang dengan persentase ketuntasan belajar siswa secara klasikal adalah 30,43\% dan jumlah siswa yang tidak tuntas sebanyak 16 orang dengan persentase secara klasikal 69,57\%.

Pada siklus II didapat jumlah siswa yang telah tuntas belajar adalah
13 orang dengan jumlah siswa adalah

23 orang dengan persentase ketuntasan belajar siswa secara klasikal adalah 56,52\% dan jumlah siswa yang tidak tuntas sebanyak 10 orang dengan persentase secara klasikal 43,48\%.

Pada siklus III didapat jumlah siswa yang telah tuntas belajar adalah 19 orang dengan jumlah siswa adalah 23 orang dengan persentase ketuntasan belajar siswa secara klasikal adalah $82,61 \%$ dan jumlah siswa yang tidak tuntas sebanyak 4 orang dengan persentase secara klasikal 17,39\%.

Tabel VII

Perbandingan Hasil Tes Siklus I, II, Dan III

\begin{tabular}{|c|c|c|c|}
\hline Siklus & Siswa & Persentase Ketuntasan Belajar & Kategori \\
\hline I & 23 & $30,43 \%$ & Kurang \\
\hline II & 23 & $56,52 \%$ & Kurang \\
\hline III & 23 & $82,61 \%$ & Baik \\
\hline
\end{tabular}

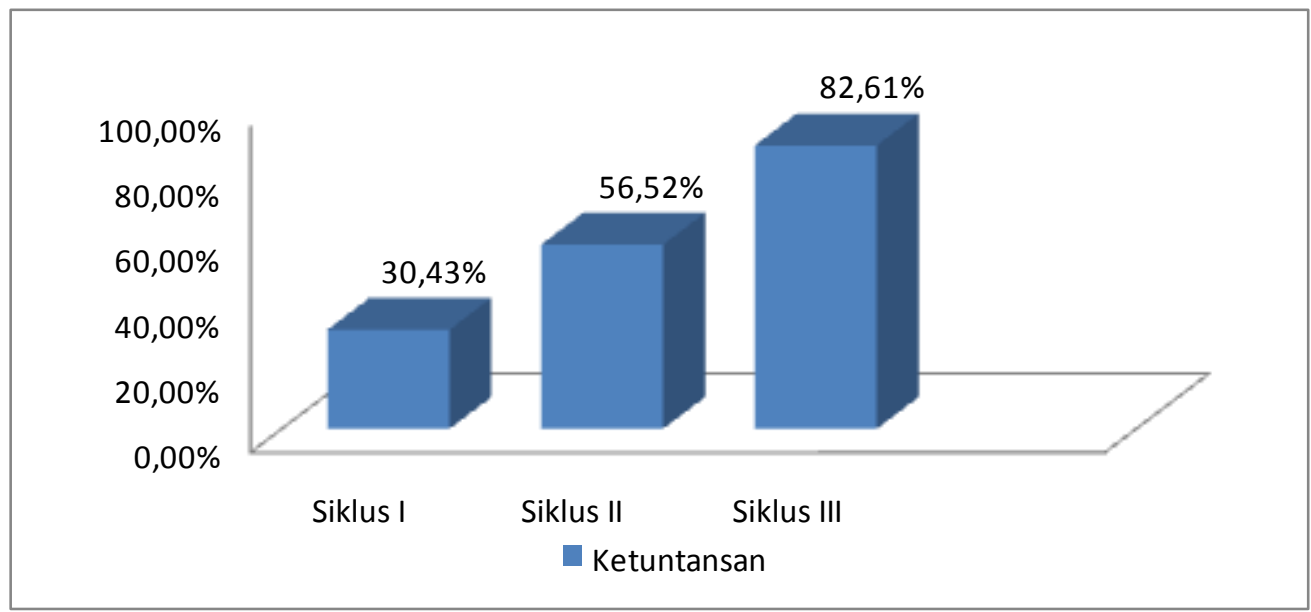

Gambar 2.Grafik perbandingan hasil tes belajar siswa siklus I, II dan III

\section{SIMPULAN}

Adapun simpulan dari penelitian ini ialah:
1. Pada siklus I didapat jumlah siswa yang telah tuntas belajar adalah 7 orang dengan jumlah siswa adalah

p-ISSN 2407-4934

e-ISSN 2355-1747 
23 orang dengan persentase ketuntasan belajar siswa secara klasikal adalah $30,43 \%$ dan jumlah siswa yang tidak tuntas sebanyak 16 orang dengan persentase secara klasikal 69,57\%..

2. Pada siklus II didapat jumlah siswa yang telah tuntas belajar adalah 13 orang dengan jumlah siswa adalah 23 orang dengan persentase ketuntasan belajar siswa secara klasikal adalah $56,52 \%$ dan jumlah siswa yang tidak tuntas sebanyak 10 orang dengan persentase secara klasikal 43,48\%.

3. Pada siklus III didapat jumlah siswa yang telah tuntas belajar adalah 19 orang dengan jumlah siswa adalah 23 orang dengan persentase ketuntasan belajar siswa secara klasikal adalah $82,61 \%$ dan jumlah siswa yang tidak tuntas sebanyak 4 orang dengan persentase secara klasikal 17,39\%

\section{DAFTAR RUJUKAN}

Aqib, Zainal. (2006). Penelitian Tindakan Kelas. Bandung: Yrama Widya.

Dimyati, dan Mudjiono. (2006). Belajar dan Pembelajaran. Jakarta: PT Rineka Cipta.

Djamarah, Syaiful Bahri dan Aswan Zain. (2006). Strategi Belajar Mengajar. Jakarta: PT Rineka Cipta.

Kemmis, S. dan Mc. Taggart, R. 2002. The Action Research Planner. Victoria Dearcin University Press.

Sagala, S. (2009). Konsep Dan Makna Pembelajaran. Bandung:

Alfabeta. 